ORIGINAL RESEARCH

\section{Occurrence of major and trace elements in powdered milk from Argentina}

\author{
FLAVIA E ARELLANO, ${ }^{1,2}$ (D) SIMONE BRAEUER, ${ }^{3}$ (D) \\ ALICIA FERNÁNDEZ CIRELLI, ${ }^{1,2}$ WALTER GOESSLER ${ }^{3}$ and ALEJO L \\ PÉREZ CARRERA ${ }^{1,2} *$ \\ ${ }^{1}$ Universidad de Buenos Aires, Facultad de Ciencias Veterinarias, Centro de Estudios Transdisciplinarios del Agua \\ (CETA), Av. Chorroarín $N^{\circ}$ 280, Buenos Aires C1427CWO Argentina, ${ }^{2}$ CONICET-Universidad de Buenos Aires, \\ Instituto de Investigaciones en Producción Animal (INPA), Av. Chorroarín 280, Buenos Aires C1427CWO Argentina, \\ and ${ }^{3}$ Institute of Chemistry, University of Graz, Universitätsplatz 3,8010 Graz, Austria
}

*Author for correspondence. E-mail: alpc@fvet.uba.ar

(C) 2019 Society of Dairy Technology

The concentrations of major and trace elements in Argentinean commercial powdered milk samples were determined with inductively coupled plasma mass spectrometry. Also the daily intake (DI) was calculated for adults and infants. The concentrations of $\mathrm{B}, \mathrm{Mg}, \mathrm{Na}, \mathrm{K}$ and $\mathrm{Ca}$ were significantly higher in skimmed milk. $\mathrm{Cu}, \mathrm{Mo}, \mathrm{Fe}, \mathrm{Mn}$ and $\mathrm{Zn}$ were significantly higher in infant formula. All the DIs were below the tolerable upper intake levels. The mean As concentration $(26.0 \pm 8.6 \mathrm{ng} / \mathrm{g}) \mathrm{in}$ the powdered skimmed milk samples was slightly higher than in the others. Mean Pb concentrations ranged from $4.1 \pm 2.1$ to $13.5 \pm 8.2 \mathrm{ng} / \mathrm{g}$. The highest mean U concentration was $7.8 \pm 2.6 \mathrm{ng} / \mathrm{g}$ for whole milk. This study contributes to the knowledge of major and trace elements in powdered milk and its contribution to the diet in Argentina.

Keywords Major elements, Trace elements, Powdered milk, Infant formula, Argentina, Daily intake, Tolerable upper intake levels.

\section{INTRODUCTION}

Dairy products are an important part of human nutrition. They provide a high content of macroand micronutrients, mostly during childhood. In the case of infants (0-12 months), milk is the main food source, covering their basic nutritional needs (Ataro et al. 2008; FAO 2012). Therefore, the determination of micro- (major and trace elements) and macrocomponents (total proteins, total fat, lactose and others) is essential to provide a safe product of good nutritional quality to consumers (Closa et al. 2003; Salah et al. 2013; Pérez-Carrera et al. 2016a; 2016b).

Several studies have characterised the composition of bovine milk and dairy products (Chilliard and Ferlay 2004; Ataro et al. 2008), including trace elements (Coni et al. 1996; Closa et al. 2003; Dobrzański et al. 2005; Qin et al. 2009; Salah et al. 2013; Bargellini et al. 2018). However, only very little data exist on trace elements in such products from the Argentinian market (Closa et al. 2003; Sigrist et al.
2016; Pérez-Carrera et al. 2016a; 2016b), although such information would be important for consumers (Argentinian Food Code-CAA). The determination of each individual element's concentration is important due to their different nutritional characteristics. For example, major elements like calcium (Ca), magnesium $(\mathrm{Mg})$, potassium $(\mathrm{K})$, sodium $(\mathrm{Na})$ and phosphorus $(\mathrm{P})$ are required by the body for bone and teeth development and fortification, muscle contraction, nerve impulses, cationic swap, osmotic regulation and other general physiological functions (Closa et al. 2003; Akpanyung 2006).

Boron (B), copper $(\mathrm{Cu})$, Iron $(\mathrm{Fe})$, zinc $(\mathrm{Zn})$, manganese $(\mathrm{Mn})$, molybdenum (Mo) and possibly vanadium (V) are only present in what in low concentrations and act as micronutrients. Other trace elements such as arsenic (As), hexavalent chromium $(\mathrm{Cr})$, lead $(\mathrm{Pb})$ and uranium (U) are toxic; hence, the daily ingested amount should not exceed the tolerable upper intake levels (ULs; Akpanyung 2006; Qin et al. 2009; NA SEM 2016). Some elements, like Cr(III), Fe 
and $\mathrm{Mn}$, are essential at a certain concentration, but can be harmful if they are consumed in excess (Licata et al. 2004; Nardi et al. 2009; Qin et al. 2009). In recent studies, the DI of dairy products is often compared with adequate intake (AI) and provisional tolerable daily intake (PTDI) levels (Salah et al. 2013; Bargellini et al. 2018).

In our study, various commercial powdered milk samples of bovine origin, taken from market shelves, were analysed for their major and trace element concentrations. The aim was to evaluate the contribution of powdered milk to the daily intake of minerals by adults and infants, especially for those elements that are considered toxic.

\section{MATERIALS AND METHODS}

\section{Samples}

Industrial milk powdered samples were taken from Argentinian primary brands on the market. The different brands were classified: 11 whole milk samples, 10 skimmed and five infant formulas, summing up a total of 26 samples, all of bovine origin (Table 6).

\section{Sample preparation}

For the determination of trace elements, the samples (three replicates per sample) were digested with $5 \mathrm{~mL}$ of nitric acid (65\%; Carl-Roth, Karlsruhe, Germany, purified via sub-boiling in-house) in a microwave-heated autoclave (MLS GmbH, Leutkirch, Germany). The digests were diluted with ultrapure water $(18.2 \mathrm{M} \Omega * \mathrm{~cm})$ to $10 \% \mathrm{v} / \mathrm{v}$ acidity.

\section{Determination of element concentrations}

Sixteen elements were determined in all samples with inductively coupled plasma mass spectrometry ICPMS (Agilent ICP-MS 7500ce, Waldbronn, Germany) at the following mass to charge ratios (m/z): As (m/z 75), Ca (m/z 43), Cr (m/z 52), Cu (m/z 65), Fe (m/z 56), K (m/z 39), Mg (m/z 24), $\mathrm{Mn}(\mathrm{m} / \mathrm{z} 55), \mathrm{P}(\mathrm{m} / \mathrm{z} 31), \mathrm{V}(\mathrm{m} / \mathrm{z} \mathrm{51})$ and $\mathrm{Zn}(\mathrm{m} / \mathrm{z} 66)$. B (m/z 11), Mo (m/z 98), Pb (m/z 208) and $U(m / z ~ 238)$ were measured without collision or reaction gas, whereas all the other elements were measured in He mode.

\section{Quality control}

Calibration standards were prepared by diluting ICP Multi Element Standard Solution VI CertiPUR ${ }^{\circledR}$ (Merck Millipore, Darmstadt, Germany) with ultrapure water and nitric acid (final acidity concentration: $10 \% \mathrm{v} / \mathrm{v}$ ). The Reference Materials SRM 1640a (Trace Elements in Natural Water, NIST, Gaithersburg, MD, USA) and IAEA-153 (Trace Elements in Milk Powder, IAEA, Vienna, Austria) were used for quality control. IAEA-153 was digested like the milk powder samples (four replicates), whereas SRM 1640a was only diluted $1+9$ with ultrapure water and nitric acid $(10 \% \mathrm{v} / \mathrm{v})$. The final concentrations were adjusted by subtracting the average values of the digestion blanks from the measured concentrations of the samples.

The stability of the ICPMS measurements was controlled by re-measuring one of the calibration standards after each 10th sample. Further, a solution consisting of $\mathrm{Ge}$, In and $\mathrm{Lu}$ was added continuously online to the samples as internal standard.

\section{Statistical analysis}

Data were analysed using Infostat software, version $2016 \mathrm{I}$. Statistical differences between the same product types from different brands were tested using one-way ANOVA (Kruskal-Wallis). Differences were considered significant at $P$ values $\leq 0.05$.

\section{Calculations}

Standardised values were used to calculate the DI for all the elements. A balanced diet of $0.06 \mathrm{~kg} /$ day of powdered milk was considered for an average $70 \mathrm{~kg}$ adult, and $0.07 \mathrm{~kg} /$ day of infant formula for an average weight $(13.93 \mathrm{~kg}$ ) baby/ child from 0 to 8 years old (WHO 2014). The risk of As, $\mathrm{Pb}, \mathrm{U}$ and $\mathrm{V}$ toxicity was estimated using the average daily intake dose (ADDI) equation for food (USEPA 1992; ATSDR 2005a; ATSDR, 2005b; USEPA 2017):

$$
\mathrm{ADDI}=\mathrm{DI} * \mathrm{EF} * \mathrm{ED} / \mathrm{BW} * \mathrm{AT}
$$

For the other elements, the following formula was used (USEPA 1992; Bargellini et al., 2018):

$$
\mathrm{DI}=\mathrm{C} * \mathrm{IR} * \mathrm{CF}
$$

where:

ADDI, average daily intake dose (in $\mathrm{mg} / \mathrm{kg} / \mathrm{d}$ )

DI, daily intake (in $\mathrm{mg} / \mathrm{d}$ )

$\mathrm{C}$, concentration of the substance analysed (in $\mathrm{mg} / \mathrm{kg}$ )

IR, daily intake rate (in $\mathrm{mg} / \mathrm{d}$ )

$\mathrm{EF}$, exposure frequency (in day/year)

$\mathrm{ED}$, exposure duration (in year)

$\mathrm{CF}$, conversion factor $\left(1 / 10^{6} \mathrm{~kg} / \mathrm{mg}\right)$

$\mathrm{BW}$, body weight of the exposed person (in $\mathrm{kg}$ )

AT, average time correction factor [ED * 365 days for noncarcinogenetic substances; statistical duration of human life (70 years) * 365 days for carcinogenetic substances].

In order to compare calculated DI values with the tolerable daily intake (TDI) levels estimated by the United States Environmental Protection Agency (USEPA) 2017 (Non-Carcinogen TDI Values), the following equation was used:

$$
\mathrm{TDI} * \mathrm{BW}
$$

\section{RESULTS}

\section{Quality control}

Table 1 shows the quality control parameters and material reference used to ensure the data accuracy. 


\section{Major elements}

Table 2 shows the concentrations determined for major elements. Mean levels for $\mathrm{Mg}$ found in skimmed milk powder were significantly higher than in whole milk powder and infant formula $(1.09 \pm 0.19, \quad 0.79 \pm 0.14 \quad$ and $0.54 \pm 0.23 \mathrm{mg} / \mathrm{g}$, respectively). A similar situation was observed for the mean concentrations of $\mathrm{Na}, \mathrm{K}$ and $\mathrm{Ca}$ (Table 2). On the other hand, no significant differences were observed for $\mathrm{P}$ mean concentrations within the different types of powdered milk.

The mean concentration of $\mathrm{Na}$ over all samples $(3.7 \pm 1.1 \mathrm{mg} / \mathrm{g})$ exceeded the values reported by Akpanyung (2006), which were $0.03-0.12 \mathrm{mg} / \mathrm{g}$, and was similar to the mean concentrations described by Nóbrega et al. (1997) in skimmed powdered milk $(4.1 \pm 0.1 \mathrm{mg} / \mathrm{g})$. At the same time, the mean concentrations (over all 26 samples) of $\mathrm{Mg} \quad(0.86 \pm 0.27 \mathrm{mg} / \mathrm{g}), \quad \mathrm{K} \quad(11.5 \pm 3.3 \mathrm{mg} / \mathrm{g}), \quad \mathrm{Ca}$ $(8.87 \pm 2.51 \mathrm{mg} / \mathrm{g})$ and $\mathrm{P}(4.14 \pm 3.38 \mathrm{mg} / \mathrm{g})$ found in this study were lower than that described by Akpanyung (2006) and Nóbrega et al. (1997). The concentration ranges reported by these authors were $1.0-1.1 \mathrm{mg} / \mathrm{g}$ for $\mathrm{Mg}, 15.0$ $17.5 \mathrm{mg} / \mathrm{g}$ for $\mathrm{K}, 10.8-11.5 \mathrm{mg} / \mathrm{g}$ for $\mathrm{Ca}$ and $6.1-9.3 \mathrm{mg} / \mathrm{g}$ for $\mathrm{P}$.

\section{Trace elements}

A significant difference between the $\mathrm{Cu}$, Mo and Fe concentrations was observed between the infant formula and skimmed and whole milk samples $(P<0.05)$. The infant formula showed higher $\mathrm{Cu}$ and $\mathrm{Fe}$ mean concentrations and lower Mo concentrations than skimmed and whole milk (Table 3, Figure 1a,b). In this case, it is known that $\mathrm{Cu}, \mathrm{Fe}$, $\mathrm{Mg}, \mathrm{Mn}$ and $\mathrm{Zn}$ were added to the infant formula with $3.66 \mu \mathrm{g} / \mathrm{g}, 64.0 \mu \mathrm{g} / \mathrm{g}, 0.44 \mathrm{mg} / \mathrm{g}, 0.77 \mu \mathrm{g} / \mathrm{g}$ and $0.04 \mathrm{mg} / \mathrm{g}$, respectively. On the other hand, the concentration of $\mathrm{B}$ in skimmed milk was significantly higher than in the infant formula and whole milk samples $(P<0.05$, Figure 1B).

As and Mo concentrations were higher than the values reported by Nardi et al. (2009) (Table 2). The opposite was

Table 1 Limits of detection (LODs), reference data of the reference materials and the determined accuracy.

\begin{tabular}{llllll}
\hline Element & $L O D(\mathrm{ng} / \mathrm{g} \cdot \mathrm{dm})$ & $\begin{array}{l}\text { NIST 1640a reference } \\
\text { value }(\mathrm{ng} / \mathrm{mL})\end{array}$ & $\begin{array}{l}\text { NIST 1640a } \\
\text { trueness }(\mathrm{n}=4)(\%)\end{array}$ & $\begin{array}{l}\text { IAEA-153 recommended } \\
\text { value }(+95 \% \text { CI })(\mu g / g)\end{array}$ & $\begin{array}{l}\text { IAEA-153 } \\
\text { trueness }(\mathrm{n}=4 \%)\end{array}$ \\
\hline $\mathrm{As}$ & 1.0 & $8.07 \pm 0.07$ & $107 \pm 9$ & Not certified & Not certified \\
$\mathrm{B}$ & 0.1 & $303.1 \pm 3.1$ & $84 \pm 11$ & $12870(12540-13$ 170) & $93 \pm 3$ \\
$\mathrm{Ca}$ & & $5615 \pm 21$ & $107 \pm 14$ & Not certified & Not certified \\
$\mathrm{Cr}$ & 3.0 & $40.54 \pm 0.30$ & $93 \pm 10$ & $0.57(0.38-0.78)^{\mathrm{a}}$ & $68 \pm 15$ \\
$\mathrm{Cu}$ & 25 & $85.75 \pm 0.51$ & $96 \pm 6$ & $2.53(1.66-3.47)$ & $83 \pm 13$ \\
$\mathrm{Fe}$ & 0.1 & $36.8 \pm 1.8$ & $102 \pm 5$ & $17620(16480-18760)$ & $83 \pm 3$ \\
$\mathrm{~K}$ & & $579.9 \pm 2.3$ & $114 \pm 10$ & $1060(1000-1150)$ & $87 \pm 15$ \\
$\mathrm{Mg}$ & & $1058.6 \pm 4.1$ & $94 \pm 14$ & $0.19(0.12-0.26)^{\mathrm{a}}$ & $104 \pm 17$ \\
$\mathrm{Mn}$ & 2.0 & $40.39 \pm 0.36$ & $90 \pm 10$ & $4180(3870-4440)$ & $78 \pm 11$ \\
$\mathrm{Mo}$ & 1.0 & $45.60 \pm 0.61$ & $100 \pm 2$ & $10100(9010-11040)$ & $85 \pm 9$ \\
$\mathrm{Na}$ & & $3137 \pm 31$ & $101 \pm 15$ & Not certified & Not certified \\
$\mathrm{P}$ & & Not certified & Not certified & Not certified & Not certified \\
$\mathrm{Pb}$ & 2.0 & $12.10 \pm 0.05$ & $89 \pm 9$ & Not certified & Not certified \\
$\mathrm{U}$ & 1.0 & $25.35 \pm 0.27$ & $95 \pm 4$ & $39.56(37.66-41.23)$ & $96 \pm 11$ \\
$\mathrm{~V}$ & 1.0 & $15.05 \pm 0.25$ & $93 \pm 6$ & & \\
$\mathrm{Zn}$ & 0.3 & $55.64 \pm 0.35$ & $90 \pm 10$ & &
\end{tabular}

${ }^{\mathrm{a}}$ Information value.

Table 2 Major elements in powered milk samples.

\begin{tabular}{lclccc}
\hline & All samples $(\mathrm{n}=26)$ & Infant formula $(\mathrm{n}=5)$ & Skimmed $(\mathrm{n}=10)$ & Whole $(\mathrm{n}=11)$ & Reference \\
\hline $\mathrm{Mg}(\mathrm{mg} / \mathrm{g})$ & $0.86 \pm 0.27$ & $0.54 \pm 0.23 \mathrm{a}$ & $1.1 \pm 0.2 \mathrm{~b}$ & $0.79 \pm 0.14 \mathrm{a}$ & $1.0-1.1$ \\
$\mathrm{Na}(\mathrm{mg} / \mathrm{g})$ & $3.7 \pm 1.0$ & $2.4 \pm 1.0 \mathrm{a}$ & $4.7 \pm 0.5 \mathrm{~b}$ & $3.4 \pm 0.4 \mathrm{a}$ & $0.02-4.06$ \\
$\mathrm{~K}(\mathrm{mg} / \mathrm{g})$ & $11.5 \pm 3.3$ & $6.6 \pm 2.6 \mathrm{a}$ & $14.9 \pm 0.5 \mathrm{~b}$ & $10.8 \pm 0.5 \mathrm{a}$ & $15.0-17.5$ \\
$\mathrm{Ca}(\mathrm{mg} / \mathrm{g})$ & $8.9 \pm 2.5$ & $5.1 \pm 2.0 \mathrm{a}$ & $11.4 \pm 0.5 \mathrm{~b}$ & $8.3 \pm 0.3 \mathrm{a}$ & $10.8-11.5$ \\
$\mathrm{P}(\mathrm{mg} / \mathrm{g})$ & $4.1 \pm 3.3$ & $3.2 \pm 1.8$ & $5.0 \pm 4.3$ & $3.8 \pm 3.0$ & $6.1-6.9$ \\
\hline
\end{tabular}

Data: different letters show significant differences, ANOVA nonparametric (Kruskal-Wallis), $P<0.05$ 
Table 3 Trace elements in powdered milk samples.

\begin{tabular}{lllccc}
\hline & $\begin{array}{l}\text { All samples }(\mathrm{n}=26) \\
\text { Range }\end{array}$ & $\begin{array}{l}\text { Infant formula }(\mathrm{n}=5) \\
\text { Mean } \pm S D\end{array}$ & $\begin{array}{l}\text { Skimmed }(\mathrm{n}=10) \\
\text { Mean } \pm S D\end{array}$ & \multicolumn{2}{c}{ Whole $(\mathrm{n}=11)$} \\
& Mean \pm SD & Reference data \\
\hline As $(\mathrm{ng} / \mathrm{g})$ & $<\mathrm{LOD}-167$ & $20.5 \pm 14.1$ & $26.0 \pm 8.6$ & $16.3 \pm 10.4$ & $6.3 \pm 0.2^{*}$ \\
$\mathrm{~B}(\mu \mathrm{g} / \mathrm{g})$ & $0.6-7.4$ & $2.44 \pm 1.59 \mathrm{a}$ & $5.15 \pm 1.20 \mathrm{~b}$ & $2.9 \pm 0.8 \mathrm{a}$ & - \\
$\mathrm{Cr}(\mathrm{ng} / \mathrm{g})$ & $<\mathrm{LOD}-102$ & $28.0 \pm 13.5$ & $25.3 \pm 9.8$ & $17.3 \pm 9.4$ & $32.0 \pm 4.0^{*}$ \\
$\mathrm{Cu}(\mu \mathrm{g} / \mathrm{g})$ & $0.12-3.64$ & $2.57 \pm 0.63 \mathrm{~b}$ & $0.23 \pm 0.05 \mathrm{a}$ & $0.19 \pm 0.05 \mathrm{a}$ & $0.18-0.24^{+}$ \\
$\mathrm{Fe}(\mu \mathrm{g} / \mathrm{g})$ & $1.5-119$ & $67.1 \pm 30.4 \mathrm{~b}$ & $2.0 \pm 0.2 \mathrm{a}$ & $1.7 \pm 0.3 \mathrm{a}$ & $99.4-118^{\bullet}$ \\
$\mathrm{Mn}(\mathrm{ng} / \mathrm{g})$ & $102-1002$ & $530 \pm 305 \mathrm{~b}$ & $188 \pm 19.9 \mathrm{~b}$ & $141 \pm 13.4 \mathrm{a}$ & $90.0-9900^{\diamond}$ \\
$\mathrm{Mo}(\mathrm{ng} / \mathrm{g})$ & $110-528$ & $198 \pm 51 \mathrm{a}$ & $385 \pm 80.6 \mathrm{~b}$ & $373 \pm 57 \mathrm{~b}$ & $36.0-47.0^{\diamond}$ \\
$\mathrm{Pb}(\mathrm{ng} / \mathrm{g})$ & $<$ LOD -45.3 & $13.5 \pm 8.2$ & $4.1 \pm 2.1$ & $5.1 \pm 2.6$ & $14.0 \pm 0.2^{*}$ \\
$\mathrm{U}(\mathrm{ng} / \mathrm{g})$ & $<$ LOD -30.7 & $5.5 \pm 1.8$ & $4.6 \pm 2.2$ & $7.8 \pm 2.6$ & - \\
$\mathrm{V}(\mathrm{ng} / \mathrm{g})$ & $5.0-260$ & $34.6 \pm 27.8$ & $41.2 \pm 26.3$ & $21.6 \pm 11.0$ & $29.8-35.6^{\diamond}$ \\
$\mathrm{Zn}(\mu \mathrm{g} / \mathrm{g})$ & $23.1-62.4$ & $43.3 \pm 13.1 \mathrm{~b}$ & $36.5 \pm 4.0 \mathrm{~b}$ & $27.0 \pm 2.4 \mathrm{a}$ & $4.2-226^{+}$ \\
\hline
\end{tabular}

Data: * mean \pm SD obtained with ICPMS by Nardi et al. (2009).

$\diamond$ Range within two determination techniques by Nardi et al. (2009).

- Range described by Akpanyung (2006).

+ Range within data obtained by Akpanyung 2006 and Nardi et al. (2009).

Data: different letters show significant differences, ANOVA nonparametric (Kruskal-Wallis), $P<0.05$.

observed for $\mathrm{Cr}$ and $\mathrm{Pb}$ mean concentrations (Table 3). In the case of $\mathrm{V}$, the average concentration found in skimmed milk exceeded the values described by Nardi et al. (2009),
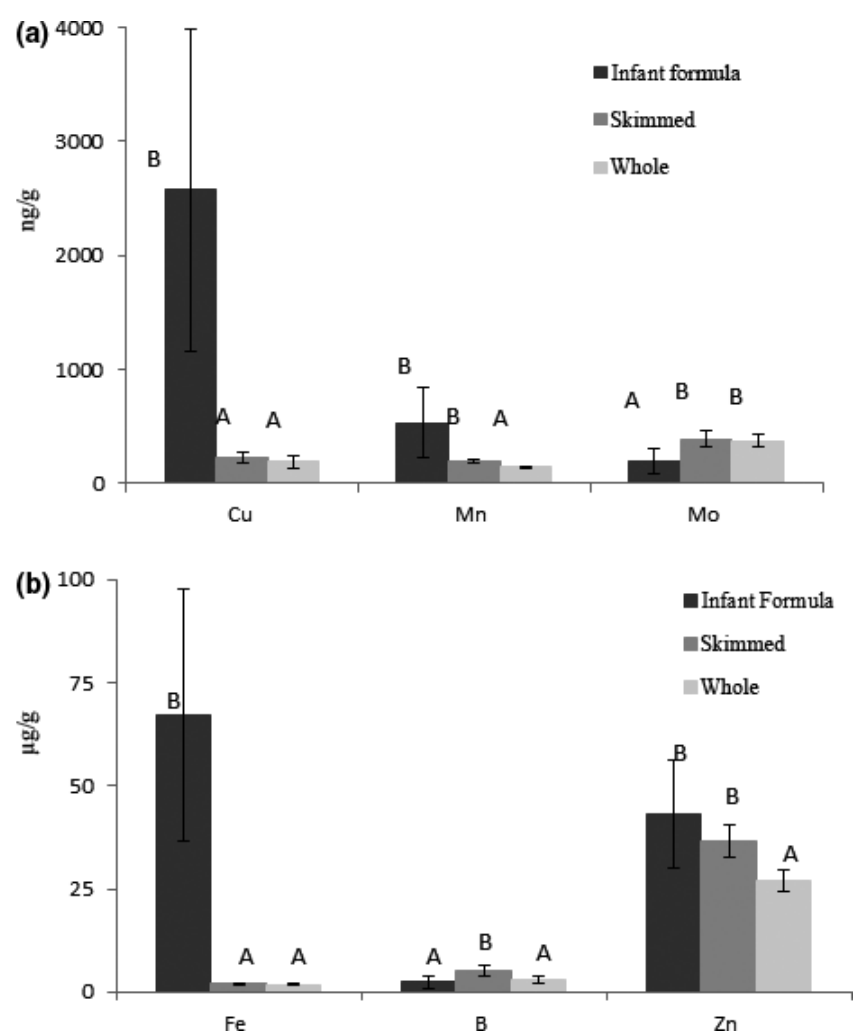

Figure 1 ( $\mathrm{a}$ and $\mathrm{b}$ ) Trace element concentrations in the different types of milk. Different letters indicate significant differences $(P<0.05)$, nonparametric ANOVA (Kruskal-Wallis). while its concentration in whole milk was below the range reported by this author (Table 2).

As to the micronutrients determined in this work, Mn, $\mathrm{Cu}$ and $\mathrm{Zn}$ concentrations were within the range published by others authors (Akpanyung 2006; Nardi et al. 2009). The exception was Fe; its mean concentration was lower than the values determined by Akpanyung (2006) (Table 3).

\section{Major and trace elements daily intake rate}

Table 4 shows the DIs of major elements through consumption of powdered milk for each age group. The calculated DIs for infants are within the recommended dietary allowances (RDAs) described by the United States National Academy of Sciences, Engineering, and Medicine (NA SEM 2016). For adults, however, all major elements were below the suggested RDAs.

The DIs of the investigated trace elements are listed in Table 5. For infants and children, the DIs for $\mathrm{Cr}, \mathrm{Fe}, \mathrm{Mn}$ and Mo were within the RDAs (NA SEM, 2016), but the DIs calculated for adults for these elements were below the RDAs. In all cases, the DIs were below the ULs (NA SEM 2016). The ADDI rate was used to calculate As exposure through consumption of milk powder products. The ingestion rate calculated for infants and children $(0.103 \pm$ $0.065 \mu \mathrm{g} / \mathrm{kg} / \mathrm{d})$ was higher than the one for adults $(0.018 \pm 0.004 \mu \mathrm{g} / \mathrm{kg} / \mathrm{d})$. In no case, the UL used by Carignan et al. (2015) $(2.1 \mu \mathrm{g} \mathrm{kg} / \mathrm{d})$ was exceeded. It has to be mentioned that this UL was only a provisional value and has been withdrawn in 2010 (EFSA 2014). The ingestion rate calculated for $\mathrm{V}$ showed that the average consumption in adults is $0.1 \%$ of the suggested UL. 
Table 4 DIs of major elements, compared with RDAs and UL for infants/children and adults.

\begin{tabular}{lllll}
\hline Major elements & Life stage group & Mean DI & RDA range & UL \\
\hline $\mathrm{Ca}(\mathrm{mg} / \mathrm{d})$ & Infants/children $(0-8$ years)Adults $(>9$ years) & $360 \pm 143585 \pm 100$ & $200-10001000-1300$ & ND2500 \\
$\mathrm{K}(\mathrm{mg} / \mathrm{d})$ & Infants/children $(0-8$ years)Adults $(>9$ years) & $461 \pm 165763 \pm 130$ & $400-38004500-5100$ & NDND \\
$\mathrm{Mg}(\mathrm{mg} / \mathrm{d})$ & Infants/children $(0-8$ years)Adults $(>9$ years) & $38 \pm 1656 \pm 13$ & $30-130240-400$ & $65-110350$ \\
$\mathrm{Na}(\mathrm{mg} / \mathrm{d})$ & Infants/children $(0-8$ years)Adults $(>9$ years) & $165 \pm 67242 \pm 48$ & $120-12001500$ & $1500-19002200-2300$ \\
$\mathrm{P}(\mathrm{mg} / \mathrm{d})$ & Infants/children $(0-8$ years)Adults $(>9$ years) & $223 \pm 126262 \pm 218$ & $100-500700-1250$ & $30003000-4000$ \\
\hline
\end{tabular}

Data: ND: not determined

Figure 2 shows the DI/RDA ratios of major and trace elements for both age groups. It can be observed that the ratio is higher for infants/children than for adults. This means that the contribution of powdered milk to the RDA of these elements is higher for infants than for adults.

Regarding the TDI values of the USEPA (2017), the DI/ TDI ratios were within $1.9-71.8 \%$ for infants, whereas for adults, they were from 0.1 to $9.1 \%$ (Figure 3 ).

\section{DISCUSSION}

The analysed commercial powdered milk samples represent a high percentage (approx. 70\%) of trademarks that the market provides for general public access in Argentina.

As for the major elements, significant differences in the concentrations of $\mathrm{Na}, \mathrm{Ca}, \mathrm{K}$ and $\mathrm{Mg}$ were observed between infant formulas and whole milk compared to skimmed milk.

Table 5 DIs of trace elements, compared with RDAs and ULs for infants/children and adults.

\begin{tabular}{|c|c|c|c|c|c|}
\hline Trace elements & Life stage group & Mean DI & $R D A$ range ${ }^{a}$ & $U L^{a}$ & $T D I^{c}$ \\
\hline As $(\mu \mathrm{g} / \mathrm{d})$ & $\begin{array}{l}\text { Infants/children }(0-8 \text { years }) \\
\text { Adults ( }>9 \text { years })\end{array}$ & $1.4 \pm 0.91 .3 \pm 0.3$ & NDND & $29.2^{\mathrm{b}} 147.0$ & 4.221 \\
\hline B (mg/d) & $\begin{array}{l}\text { Infants/children }(0-8 \text { years }) \\
\text { Adults ( }>9 \text { years })\end{array}$ & $0.2 \pm 0.10 .2 \pm 0.1$ & NDND & $<6.011-20$ & 2.8 \\
\hline $\mathrm{Cr}(\mu \mathrm{g} / \mathrm{d})$ & $\begin{array}{l}\text { Infants/children }(0-8 \text { years }) \\
\text { Adults ( }>9 \text { years) }\end{array}$ & $2.0 \pm 0.91 .3 \pm 1.1$ & $0.2-1520-45$ & NDND & $\begin{array}{l}1500(\mathrm{Cr} \text { III }) 3.0 \\
(\mathrm{Cr} \mathrm{VI})\end{array}$ \\
\hline $\mathrm{Cu}(\mathrm{mg} / \mathrm{d})$ & $\begin{array}{l}\text { Infants/children }(0-8 \text { years }) \\
\text { Adults ( }>9 \text { years })\end{array}$ & $0.2 \pm 0.112 .6 \pm 3.3^{\mathrm{d}}$ & $200-440700-1300$ & $<30005000-10000$ & 557.22800 \\
\hline $\mathrm{Fe}(\mathrm{mg} / \mathrm{d})$ & $\begin{array}{l}\text { Infants/children }(0-8 \text { years }) \\
\text { Adults ( }>9 \text { years) }\end{array}$ & $4.7 \pm 2.10 .11 \pm 0.02$ & $0.27-118-27$ & $4040-45$ & 9.749 \\
\hline $\mathrm{Mn}(\mathrm{mg} / \mathrm{d})$ & $\begin{array}{l}\text { Infants/children }(0-8 \text { years }) \\
\text { Adults ( }>9 \text { years) }\end{array}$ & $0.037 \pm 0.0210 .010 \pm 0.002$ & $0.003-1.51 .6-2.6$ & $2.0-3.06 .0-11.0$ & 1.99 .8 \\
\hline Mo $(\mu \mathrm{g} / \mathrm{d})$ & $\begin{array}{l}\text { Infants/children }(0-8 \text { years }) \\
\text { Adults ( }>9 \text { years) }\end{array}$ & $13.9 \pm 3.522 .7 \pm 4.0$ & $2-2234-50$ & $<6001100-2000$ & 69.6350 \\
\hline $\mathrm{Pb}(\mathrm{ng} / \mathrm{d})$ & $\begin{array}{l}\text { Infants/children }(0-8 \text { years }) \\
\text { Adults ( }>9 \text { years) }\end{array}$ & $0.9 \pm 0.60 .28 \pm 0.03$ & NDND & NDND & 50250 \\
\hline $\mathrm{U}(\mathrm{ng} / \mathrm{d})$ & $\begin{array}{l}\text { Infants/children }(0-8 \text { years }) \\
\text { Adults ( }>9 \text { years) }\end{array}$ & $0.38 \pm 0.120 .37 \pm 0.09$ & NDND & NDND & 2.814 \\
\hline $\mathrm{V}(\mathrm{ng} / \mathrm{d})$ & $\begin{array}{l}\text { Infants/children }(0-8 \text { years }) \\
\text { Adults ( }>9 \text { years })\end{array}$ & $2 \pm 21.9 \pm 0.6$ & NDND & $\mathrm{ND}<1800$ & 1470 \\
\hline $\mathrm{Zn}(\mathrm{mg} / \mathrm{d})$ & $\begin{array}{l}\text { Infants/children }(0-8 \text { years }) \\
\text { Adults ( }>9 \text { years })\end{array}$ & $3.0 \pm 0.91 .9 \pm 0.3$ & $2-58-13$ & $4-1223-40$ & 4.221 \\
\hline \multicolumn{6}{|l|}{ Data: } \\
\hline \multicolumn{6}{|c|}{ ND: not determined. } \\
\hline \multicolumn{6}{|c|}{ a'NA SEM (2016). } \\
\hline \multicolumn{6}{|c|}{${ }^{\mathrm{b}}$ Reference data from Carignan et al. (2015). } \\
\hline
\end{tabular}


There was no significant difference in the concentration of $\mathrm{P}$ between infant formulas and skimmed and whole milk. It was observed that the intake rate found for those elements covered the basic needs of infants (from 0 to 12 months) described by the NA SEM. However, children (from 1 to 8 years) require complementary contributions to the diet (Table 3). The intake of $\mathrm{Ca}, \mathrm{Mg}$ and $\mathrm{P}$ is required for bones and teeth development and fortification. In addition, these elements are also required together with $\mathrm{Na}$ and $\mathrm{K}$ for metabolic processes, such as synthesis of proteins and DNA, nerve impulses, muscle contraction and relaxation and osmotic balance, among others. For adults, all the major elements are below the range suggested by the NA SEM (2016) (Figure 2a). However, adults usually cover the daily
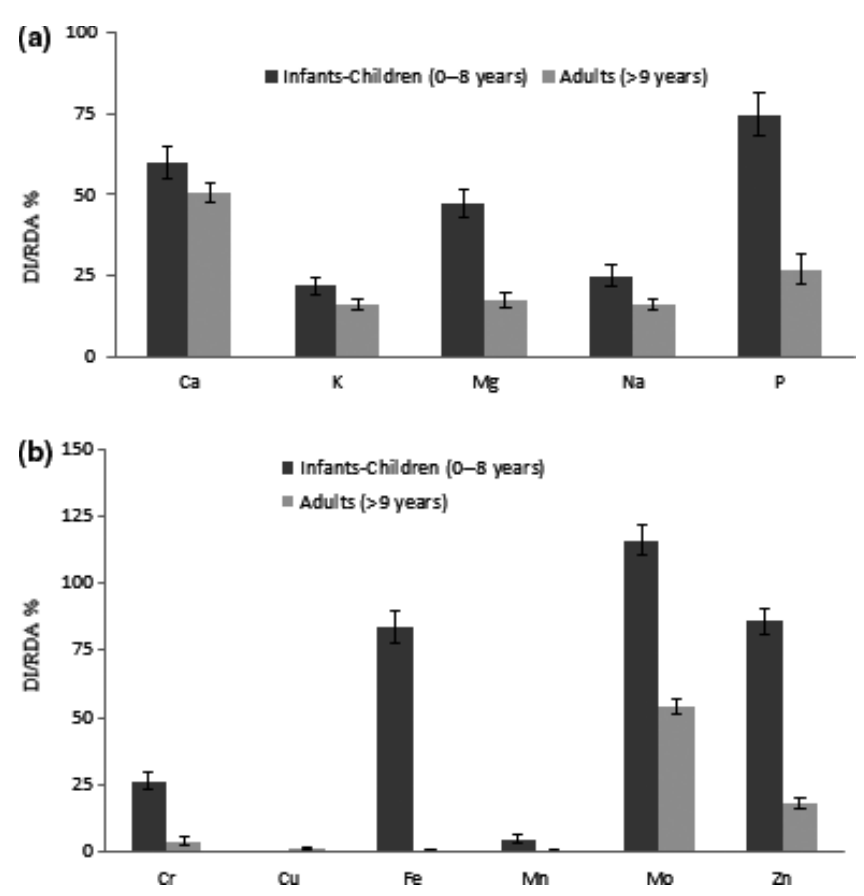

Figure 2 ( $a$ and b) DI/RDA ratios (\%) of major and trace elements for infants/children $(0-8$ years $)$ and adults $(<9$ years $)$.

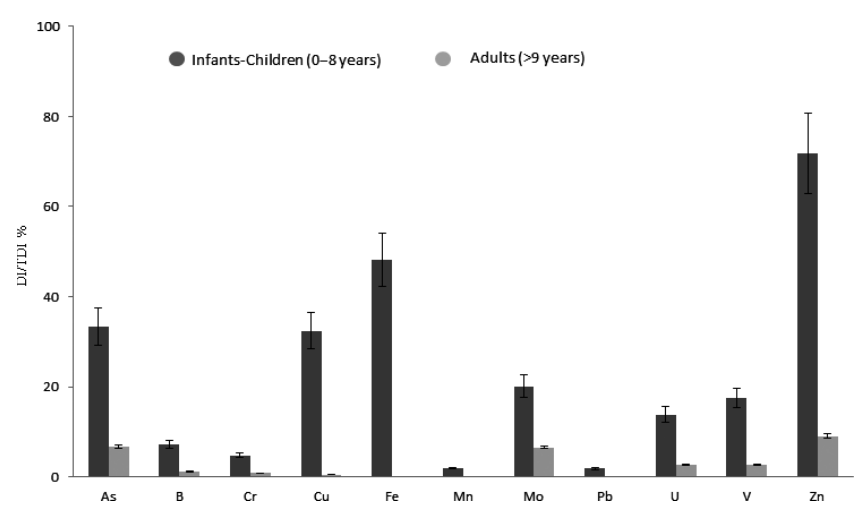

Figure 3 DI/TDI ratios (\%) of major and trace elements for infants/children $(0-8$ years) and adults ( $<9$ years). requirements of the various elements by a balanced diet that includes all kinds of different food, not just dairy.

Regarding the analysed trace elements, a high variability in the determined concentrations was observed. In general, the range obtained for trace elements was between the values described by other authors (Table 2). There is only very little information in literature about $\mathrm{B}$ and $\mathrm{U}$ in powdered milk.

Taking into account the DI values suggested by the Food and Nutrition Board of the Institute of Medicine of the NA SEM 2016), the DIs obtained do not exceed RDAs and ULs. Despite this, it is important to note that long-term exposure to As, $\mathrm{Cr}(\mathrm{VI}), \mathrm{Pb}$ and $\mathrm{U}$ can lead to health problems (Akpanyung 2006; Ataro et al. 2008; Nardi et al. 2009; Qin et al. 2009). In the case of $\mathrm{Cr}$ (assuming it is not in the hexavalent form), the calculated DI is sufficient for infants and children, but it was below the RDA range suggested for adults (Table 4, Figure 2a,b). For As, the ADDI was higher for infants and children than for adults. In no case, the (former) UL of $2.1 \mu \mathrm{g} / \mathrm{kg} \cdot \mathrm{d}$ was exceeded (Carignan et al. 2015) (Table 4). Regarding $\mathrm{Pb}$, it is known that exposure can lead to a delay of the cognitive development of children, among other effects (Ataro et al. 2008). In this case, there is no RDA or UL (2016). Even so, the $\mathrm{Pb}$ mean concentrations found do not exceed those reported by other authors (Nardi et al. 2009; Abdulkhaliq et al. 2012). With regard to U, high concentrations of natural origin can be found in the Argentinian environment. Its concentrations in the samples analysed were low, and the exposure by ingestion is low as well. When comparing the TDI (USEPA 2017) values for Pb and U with the DI/ RDA and the DI/TDI, it is possible to see differences between infant/child and adult intake. In none of the cases, shown in Figure 3, values exceed the ones suggested by the USEPA. Meanwhile, Mo levels are above the RDA (Figure 2NA SEM (2)).

\section{CONCLUSIONS}

In conclusion, this study contributes to the knowledge of toxic elements, macro- and micronutrients in powdered milk on the Argentinian market. This is important to ensure a safe and nutritive intake of this product. According to our data, an average daily consumption of $0.07 \mathrm{~kg}$ infant formula can cover the recommended intake levels of infants/ children, whereas a daily portion of $0.06 \mathrm{~kg}$ powdered milk is not sufficient to cover the required amounts of major and trace elements for adults. Further, the concentrations of the (potentially) toxic elements are too low to pose an immediate health risk for consumers.

\section{ACKNOWLEDGEMENTS}

Authors are indebted to the University of Buenos Aires and to CONICET (National Research Council) for financial support. 


\section{REFERENCES}

Abdulkhaliq A, Swaileh K M, Hussein R M and Matani M (2012) Levels of metals $(\mathrm{Cd}, \mathrm{Pb}, \mathrm{Cu}$ and $\mathrm{Fe})$ in cow's milk, dairy products and hen's eggs from the West Bank, Palestine. International Food Research Journal 19 1089-1094.

Agency for Toxic Substances and Disease Registry (ATSDR) (2005a) Appendix G: calculation exposure doses [Internet document] URL https://www.atsdr.cdc.gov/hac/phamanual/appg.html Accessed 20/07/ 2017.

Agency for Toxic Substances and Disease Registry (ATSDR). (2005b) Public Health Assessment Guidance Manual (Update) [Internet document] URL https://www.atsdr.cdc.gov/hac/phamanual/pdfs/phagm_f inal1-27-05.pdf Accessed 20/07/2017.

Akpanyung E O (2006) Major and trace element levels in powdered milk. Pakistan Journal of Nutrition 5 198-202.

Ataro A, McCrindle R I, Botha B M, McCrindle C M E and Ndibewu P P (2008) Quantification of trace elements in raw cow's milk by inductively coupled plasma mass spectrometry (ICP-MS). Food Chemistry 111 243-248.

Bargellini A, Venturelli F, Casali E, Ferrari A, Marchesi I and Borella P (2018) Trace elements in starter infant formula: dietary intake and safety assessment. Environmental Science and Pollution Research $\mathbf{2 5}$ 2035-2044.

Carignan C, Cottingham K L, Jackson B P, Farzan S F, Gandolfi A J, Punshon T, Folt C L and Karagas M R (2015) Estimated exposure to arsenic in breastfed and formula-fed infants in a United States cohort. Environmental Health Perspectives 123 500-506.

Chilliard Y and Ferlay A (2004) Dietary lipids and forages interactions on cow and goat milk fatty acid composition and sensory properties. Reproduction nutrition Development 45 467-492.

Closa S J, de Landeta M C, Andérica D, Pighín A and Cufré J A (2003) Contenido de nutrientes minerales en leches de vaca y derivados de Argentina. Archivos latinoamericanos de Nutrición 53 320-324.

Código Alimentario Argentino, Argentinian Food Code, CAA (2012) Reglamento técnicos Mercosur sobre límites máximos de contaminantes inorgánicos en alimentos [Internet document] URL http://www.a nmat.gov.ar/alimentos/codigoa/Capitulo_III.pdf. Accessed 26/07/2017.

Coni E, Bocca A, Coppolelli P, Caroli S, Cavallucci C and Trabalza Marinucci M (1996) Minor and trace element content in sheep and goat milk and dairy products. Food Chemistry 57 253-260.

Dobrzański Z, Kolacz R, Górecka H, Chojnacka K and Bartkowiak A (2005) The content of microelements and trace elements in raw milk from cows in the Silesian Region. Polish Journal of Environmental Studies 14 685-689.

European Food Safety Authority (EFSA) (2014) Dietary exposure to inorganic arsenic in the European Population. European Food Safety Authority Journal 123597.

Food and Agriculture Organization (FAO) (2012) Dairy products in human nutrition: Questions and Answers. Food and Agriculture
Organization. [Internet document] URL http://www.fao.org/docrep/ 018/i3396e/i3396e.pdf. Milk and Dairy Q\&A. Accessed 20/07/2017.

Licata P, Trombetta D, Cristani M, Giofré F, Martino D, Caló M and Naccari F (2004) Levels of "toxic" and "essential" metals in samples of bovine milk from various dairy farms in Calabria, Italy. Environment International 30 1-6.

Nardi E P, Evangelista F S, Tormen L, Saint'Pierre T D, Curtius A J, Souza S S and Barbosa F (2009) The use of inductively coupled plasma mass spectrometry (ICP-MS) for the determination of toxic and essential elements in different types of food samples. Food Chemistry 112 727-732.

National Academy of Sciences, Engineering and Medicine (NA SEM) (2016) Dietary Reference Intakes. Food and Nutrition Board, Institute of Medicine, NA SEM. [Internet document] URL http://www.nationa lacademies.org/hmd/Activities/Nutrition/SummaryDRIs/DRI-Tables.a spx. Accessed 29/06/2017.

Nóbrega J A, Gélinas Y, Krushevska A and Barnes R M (1997) Direct Determination of Major and Trace Elements in Milk by Inductively Coupled Plasma Atomic Emission and Mass Spectrometry. Journal of Analytical Atomic Spectrometry 12 1243-1246.

Pérez-Carrera A, Alvarez-Gonçalvez C V and Fernández-Cirelli A (2016a) Transference factors as a tool for the estimation of arsenic milk concentration. Environmental Science and Pollution Research 23 16329-16335.

Pérez-Carrera A, Arellano F E and Fernández-Cirelli A (2016b) Concentration of trace elements in raw milk from cows in the southeast of Córdoba province. Argentina. Dairy Science and Technology. 96 591-602.

Qin L, Wang X, Li W, Tong X and Tong W (2009) The minerals and heavy metals in Cow's milk from China and Japan. Journal of Health Sciences 55 300-305.

Salah F A A, Esmat I A and Mohamed A B (2013) Heavy metals residues and trace elements in milk powder marketed in Dakahlia Governorate. International Food Research Journal 20 1807-1812.

Sigrist M, Hilbe N, Brusa L, Campagnoli D and Beldoménico H (2016) Total arsenic in selected food samples from Argentina: Estimation of their contribution to inorganic dietary intake. Food Chemistry 210 96-101.

United States Environmental Protection Agency (USEPA) (1992) Guidelines for exposure assessment, Environmental Protection Agency, Risk Assessment Forum, Washington (DC). Federal Register 57 22888-22938

United States Environmental Protection Agency (USEPA) (2017) Noncarcinogen tolerable daily intake (TDI) values from US EPA [Internet document] URL http://www.popstoolkit.com/tools/HHRA/TDI_USE PA.aspx. Accessed 02/04 2017.

World Health Organization (WHO) (2014) WHO child growth standards [Internet document] URL http://www.who.int/childgrowth/standarswe ight_for_age/en/. Accessed 20/04/2017. 


\section{APPENDIX}

Table A1 Package basic composition described for a $200 \mathrm{~mL}$ of restored milk (per portion)

\begin{tabular}{|c|c|c|c|c|c|}
\hline \multirow[b]{2}{*}{$\mathrm{N}$} & \multirow{2}{*}{$\begin{array}{l}\text { Whole } \\
11\end{array}$} & \multicolumn{2}{|l|}{ Skimmed } & \multicolumn{2}{|l|}{ Infant formula } \\
\hline & & 9 & 1 & 4 & 1 \\
\hline Basic formula & $\begin{array}{l}\text { Whole milk, soy } \\
\text { lecithin \& } \\
\text { vitamins A \& D }\end{array}$ & $\begin{array}{l}\text { Skimmed milk, soy } \\
\text { lecithin \& } \\
\text { vitamins A \& D }\end{array}$ & $\begin{array}{l}\text { Skimmed milk, } \\
\text { soy lecithin, } \\
\text { vitamins B2 \& B12, P } \\
\& \mathrm{Ca}\end{array}$ & $\begin{array}{l}\text { Lactose, whey } \\
\text { protein, } \\
\text { skimmed milk, } \\
\text { vegetable oils, } \\
\text { nutrients }\end{array}$ & $\begin{array}{l}\text { Skimmed milk, } \\
\text { soy lecithin, } \\
\text { vitamins A, B \& D, P } \\
\text { \& Ca }\end{array}$ \\
\hline Fat $(\mathrm{g})$ & $6.61 \pm 0.15$ & $0.14 \pm 0.05^{\mathrm{a}}$ & & $6.20 \pm 0.75$ & 7.00 \\
\hline Protein $(\mathrm{g})$ & $6.38 \pm 0.46$ & $6.46 \pm 0.66^{\mathrm{a}}$ & & $3.15 \pm 0.77$ & 6.80 \\
\hline $\begin{array}{l}\text { Vitamin A } \\
(\mu \mathrm{g})\end{array}$ & $130.3 \pm 1.8$ & $127.0 \pm 1.1$ & ND & $155.5 \pm 46.4$ & 187.0 \\
\hline $\begin{array}{l}\text { Vitamin B2 } \\
(\mathrm{mg})\end{array}$ & $0.28 \pm 0.01$ & $0.27 \pm 0.02^{\mathrm{a}}$ & & $0.19 \pm 0.01$ & 0.31 \\
\hline $\begin{array}{l}\text { Vitamin B9 } \\
(\mu \mathrm{g})\end{array}$ & $0.36 \pm 0.01$ & ND & & $21.5 \pm 2.9$ & ND \\
\hline $\begin{array}{l}\text { Vitamin B12 } \\
(\mu \mathrm{g})\end{array}$ & $0.57 \pm 0.29$ & $0.32 \pm 0.01^{\mathrm{a}}$ & & $0.38 \pm 0.02$ & 0.36 \\
\hline $\begin{array}{l}\text { Vitamin D } \\
(\mu \mathrm{g})\end{array}$ & $2.02 \pm 0.04$ & $1.60 \pm 0.35$ & ND & $2.32 \pm 0.35$ & 1.80 \\
\hline $\mathrm{Na}(\mathrm{mg})$ & $129.5 \pm 1.7$ & $94.4 \pm 9.7$ & 112.0 & $47.7 \pm 11.6$ & 92.0 \\
\hline $\mathrm{Ca}(\mathrm{mg})$ & $226.4 \pm 24.6$ & $248.3 \pm 3.14^{\mathrm{a}}$ & & $124.5 \pm 28.8$ & 245.0 \\
\hline $\mathrm{P}(\mathrm{mg})$ & $193.0 \pm 11.5$ & $195.7 \pm 4.8^{\mathrm{a}}$ & & $80 \pm 37$ & 199.0 \\
\hline $\mathrm{Fe}(\mathrm{mg})$ & ND & ND & & $1.67 \pm 0.18$ & 3.1 \\
\hline $\mathrm{Mg}(\mathrm{mg})$ & ND & ND & & $11.51 \pm 1.75$ & 22 \\
\hline $\mathrm{Zn}(\mathrm{mg})$ & ND & ND & & $1.26 \pm 0.03$ & 1.3 \\
\hline $\mathrm{Cu}(\mu \mathrm{g})$ & ND & ND & & $95.2 \pm 9.85$ & ND \\
\hline $\operatorname{Mn}(\mu \mathrm{g})$ & ND & ND & & $20.7 \pm 6.04$ & ND \\
\hline
\end{tabular}

